\title{
Mirrors and Metarealists: The Poetry of Ol'ga Sedakova and Ivan Zhdanov
}

\section{Citation}

Sandler, Stephanie. 2006. Mirrors and metarealists: the poetry of Ol'ga Sedakova and Ivan Zhdanov. Slavonica 12(1): 3-25.

\section{Published Version}

doi:10.1179/174581406X94119

\section{Permanent link}

http://nrs.harvard.edu/urn-3:HUL.InstRepos:5387058

\section{Terms of Use}

This article was downloaded from Harvard University's DASH repository, and is made available under the terms and conditions applicable to Other Posted Material, as set forth at http:// nrs.harvard.edu/urn-3:HUL.InstRepos:dash.current.terms-of-use\#LAA

\section{Share Your Story}

The Harvard community has made this article openly available.

Please share how this access benefits you. Submit a story.

Accessibility 


\title{
MIRRORS AND METAREALISTS: THE POETRY OF OL'GA SEDAKOVA AND IVAN ZHDANOV
}

\author{
STEPHANIE SANDLER
}

\author{
Harvard University
}

\begin{abstract}
Ol'ga Sedakova and Ivan Zhdanov, two prominent contemporary metarealist poets, depart from traditional mirror poems' reliance on straightforward reflection or description. Their mirror poems elucidate their idiosyncratic poetic systems and, particularly in the case of Zhdanov, they balance metaphor with compelling metonymies and create a valuable connection to the poetry of Boris Pasternak. Zhdanov and Sedakova use mirrors to call attention to the artifice of poetry and to expose to visibility the workings of the poet's mind as the poem is created. In Sedakova's poetry, the poems show surprising flashes of darkness and, in Zhdanov's poems, the mirrors often reveal unusual depths. The essay pursues two overarching questions: 'What do mirrors show us about poetic language?' and 'How do mirrors allow poetry to suggest a theory of subjectivity?' Both questions ask that poems show us their theories of language and of identity. Several poems by each poet are read closely and the readings are used to draw more general conclusions about the possibilities for penetration, transcendence, and revelation in their work.
\end{abstract}

The relationship between words and images remains a compelling problem in cultural and philosophical theory, and we are undoubtedly still experiencing that stage of intellectual history that W. J. T. Mitchell called 'the pictorial turn' more than a decade ago. ${ }^{1}$ Contemporary poets continue to explore the relationship of writing to seeing productively and also selfconsciously. The most interesting of these poets put the sights of the visible world and their own mental pictures into words while sharing an account of the thought processes involved. To write such poetry is to produce a record of the creative act, and to read such poetry is to experience a poetic world where images can speed past in a dizzying slide show of the imagination, if not the unconscious.

Poets in the United States, Britain, France and elsewhere could provide compelling material for a study of this intersection of the verbal and the visual, and I will refer to their work below. But my attention will focus on two Russian poets who have made the 'pictorial turn' central to their work, Ol'ga Sedakova and Ivan Zhdanov. They may seem a natural pairing, although the connections between them have been asserted rather than analyzed (explaining how their mutual connections work will be a secondary goal of this essay). Both Sedakova and 
Zhdanov were named as Metarealists, a term coined by Mikhail Epshtein in the I980s for an alternative poetic trend to Moscow conceptualism. ${ }^{2}$ Metarealism and conceptualism are still with us, more than twenty years later, although in diminished form. The conceptualists, as Epshtein defined them, were eager to reject the norms of poetic language in favour of exposing the cultural myths and social practices of Soviet culture, whereas the Metarealists stayed with the language and themes of modernist poetry while pushing them toward greater self-consciousness, if not self-doubt. Metarealists explore philosophical and spiritual questions, even in a secular and ironic world; they pursue multiple realities (although without the hierarchies of Symbolism), and they share a penchant for adventurous and dense metaphor. For this last reason, Konstantin Kedrov named them, rather awkwardly, metametaphorists. ${ }^{3}$ His term fitted the work of Ivan Zhdanov especially well: it is fair to say that Zhdanov reveals a fascination with multiple metaphors more than does Sedakova and, as a result, the dense texture of his work is more like that of other supposed Metarealists - Aleksei Parshchikov and Arkadii Dragomoshchenko, for example.

Zhdanov and Sedakova were, and perhaps still are, friends. Zhdanov spent time in Moscow beginning in the I970s (he is originally from the Altai region and, to the best of my knowledge, he now lives in the Crimea and works largely as a photographer; Sedakova continues to live in Moscow and remains an active poet, translator, teacher, and scholar). Traces of their friendship appear in poems that directly speak to one another or use poetic dedications. In this connection, they stand together in a way that we cannot say for most other Metarealists, who are generally idiosyncratic poets, polite about one another's work with occasional, nearly friendly gestures at one another. In this relative standoffishness, we have a stark contrast to the Moscow conceptualists. Dmitrii Prigov, Timur Kibirov and Lev Rubinshtein parade their friendships in their work, reaching to others, like Sergei Gandlevskii, in public displays of masculine camaraderie. Zhdanov and Sedakova lack this easily accessible category for their connection, although each sees something familiar in the work of the other, for all its strange differences. The mirror of the other's poetry, we might say, provides something other than an exact reflection, which describes the way in which mirrors work in their poetry in general.

The prominence of mirrors in this poetry is both distinctive to Sedakova's and Zhdanov's work and, like the prominence of the visual more generally, part of a larger trend. The mirror as a device in modern art and poetry suggests a fascination with difficulty and, perhaps, selfabsorption. To choose a mirror (rather than, say, a window), is to choose against transparence, to choose an obstacle of sorts, to rephrase Jean Starobinski's celebrated book title. ${ }^{4}$ Starobinski was writing about Rousseau in the eighteenth century and, particularly in the modern and post-modern periods, the glass of transparence has again become palpable, as poets ask us to notice the eyepiece through which a world is viewed. When poets offer us not glass, but mirrors, they turn away from the world: their concern is an inner gaze, one that exposes a self-regarding subject who might otherwise be hidden. ${ }^{5}$

Zhdanov and Sedakova, however, principally turn to mirrors in order to expose the working of thought itself. The glances outward at the world and inward to the self are not mutually exclusive in their work and, more important, they abstract the mirror's capacities for reflection into a problem of what is seen and what is obscured by the process of poetic creation. To go beyond the looking glass is to enter the fantasy world of Alice in Wonderland, they might insist, which lets one explore the nature of fantasy itself. Mirrors are what these poets hold up not to their faces but to their creative imaginations, and the inclusion of a mirror in a poem potentially becomes a form of baring the device ('obnazhenie priema', as the Formalists called it). ${ }^{6}$ 
Sedakova and Zhdanov are drawn to mirrors as to magnets. They use them in a wonderfully counter-intuitive way - to call attention to the artifice of their poetry, but also to expose to visibility the workings of a poet's mind as the poem is created. They overturn several foundational premises for mirror poems and, in the process, they make the mirror a signature. ${ }^{7}$ Sedakova often has someone else look into a mirror, creating poems written in the third person and spoken with some irony. Access to interior worlds maps the pathway of many of Sedakova's poems, but the distances travelled grow vast, allowing the inner spaces of spirituality and subjectivity to mirror the cosmic enormity of a world divinely ordered. These journeys emerge less as dynamic experiences of movement than as stilled concentrations of thought, closer to still life painting, in fact, than to portraiture. Sedakova has rightly become known for her luminosity of surface; a surprise of her mirror poems is their recurrent flash of darkness. Ivan Zhdanov (born I948, he is Sedakova's exact contemporary) has much in common with her, including the larger metaphysical concern for the meaning of being, but his world emerges as a more dynamic, quickly changing landscape, and he is more likely to layer the relationship between portraiture and mirroring. ${ }^{8}$ Depth plays a crucial role in his metaphors. He is elusive in his acts of self-description - like Sedakova, he sends the reader's gaze repeatedly off to the side. He, too, impedes the exchange of glances between a subject and a mirror, or between a reader and a poem. The dense metaphors become the main pleasure of many poems, and they often work as metonymies, particularly in his poems about mirrors.

Charles Lock has observed that mirror reflections, like shadows, are at once metonymy and metaphor, which for him explains their cultural prestige. ${ }^{9}$ Mirrors, I want to argue, open out new possibilities for interactions among a poem's tropes, and they redirect the work of selfinspection that can no longer be a simple effusion of authentic utterance. This is particularly true for many poets writing after Rilke or Pasternak or Mandel'shtam — all three important to Zhdanov and Sedakova. I will pursue here, then, two overarching questions: 'What do mirrors show us about poetic language?' and 'How do mirrors allow poetry to suggest a theory of subjectivity?' Both these questions ask of poems that they show us their theories - of language, and of identity. My goal is to ask these questions while respecting the place of individual poems in a poetic tradition. To that end, I will offer observations on metre, form, sound and subtext, as well as on the nature of trope and identity in several of the poets' most interesting poems about mirrors.

Having mentioned the friendship of Sedakova and Zhdanov, I should begin with poems that document their mutual admiration. Sedakova, who quickly recognized the mysterious beauty of Zhdanov's poetic world, dedicated two poems to him. The first, 'Vesna' ('Spring'), has the feel of a beautifully danced celebration. ${ }^{10}$ It strikes a welcoming, hopeful note, inviting Zhdanov to come out from the darkness and distance as it urges the arrival of spring. 'Vesna' speaks to him by adverting to the poetry of Velimir Khlebnikov. ${ }^{11}$ Jens Herlth has written well about the way this poem absorbs the lessons of Khlebnikov's play with morphology and sound, pointing out how the poem also revises Tiutchev's 'Vesna'. ${ }^{12}$ The second poem from Sedakova to Zhdanov is 'Elegiia smokovnitsy' ('Elegy for the Fig Tree'). It conjures Boris Pasternak as intermediary, which, as we shall see in Zhdanov's poetry, is singularly appropriate. ${ }^{13}$ The elegy begins:

дерево, Ваня, то самое, смоковницу ту

на старой книжной гравюре, на рыхлой бумаге верже узнаешь? ${ }^{14}$

That tree, Vania, the very one, the fig tree

in an old engraving in a book, on porous laid paper, do you recognize it? 
The poet invites Zhdanov to contemplate a picture based on a Biblical story and, as the poem unfolds, to hear in the Biblical story its parable about unworthiness. Sedakova goes beyond the parable to speak in Christian terms of forgiveness, which gives her poem a consolatory and redemptive feel. ${ }^{15}$ She treats the engraving of the fig tree as a mirror, but one that reflects the soul ${ }^{16}$ in her act of ekphrasis, the poet sees in an image a story about human spiritual experience and divine knowledge, as if in answer to moments in Zhdanov's poems where vision fails. ${ }^{17}$ Sedakova is more likely than is Zhdanov to use the paradoxes of Christianity to write about the mysterious power of art and her mirrors offer visibility and obscurity in the same flash of light. When the mirrors present an opportunity for self-contemplation, as in her poem 'Gospozha i sluzhanka' ('The Mistress and the Servant'), the gesture is at best ambivalent: 'Zachem sebia izuchat'?' ('Why do we study ourselves?'), asks that poem. ${ }^{18}$ Mirrors in these poems open up an aperture for revelation rather than self-admiration, and Sedakova's mirrors deflect or refract light as easily as they reflect it. ${ }^{19} \mathrm{I}$ turn now to a series of sustained readings of individual poems.

Sedakova: Reflecting the Minuscule, Seeing an Angel

One of Sedakova's Starye pesni (Old Songs, I980-1981) is entitled 'Zerkalo' ('The Mirror'), and the title gives the mirror a prominence in the poem it might not otherwise have.

Зеркало

Милый мой, сама не знаю:

к чему такое бывает? -

зеркальце вьется рядом

величиной с чечевицу

или как зерно просяное.

А что в нем горит и мнится, смотрит, видится, сгорает лучше совсем не видеть.

Жизнь ведь - небольшая вещица:

вся, бывает, соберется

на мизинце, на конце ресницы.

А смерть кругом нее, как море. ${ }^{20}$

The Mirror

My dear, I do not know this myself:

why do such things happen to exist? -

The little mirror twists and turns right here,

the size of a lentil

or like a grain of millet.

And what burns and flickers in it, what looks out, appears, burns down better not to see this at all.

Life, after all, is a tiny little thing: all of it, as it happens, can be gathered up on a little finger, on the end of an eyelash.

But death is all around it, like the sea. 
'Zerkalo' challenges visibility by its minuscule terms of comparison. The poet places all of life in tiny grains and legumes, as if the seeds of life were replicated in the concentration of potential in miniature. ${ }^{21}$ The mirror, like the life it would appear to reflect, is small - even the poem is small; all of Sedakova's Starye pesni have this brevity and simplicity. The mirror fits miraculously into tiny spaces like a little finger or an eyelash. What is seen is contiguous with the body, and the body parts chosen for mention are themselves a kind of metonymy, finger a part of hand, eyelash a part of eye. Like Zhdanov, Sedakova presents the poet's body to the mirror in its two most important aspects, the eye that sees the world, the hand that writes the poem. ${ }^{22}$

Formally, 'Zerkalo' is typical for Sedakova's Starye pesni. The metre tends toward the trochaic, but technically this is accentual verse, appropriate to literary recreation of folk songs (a predecessor here is Pushkin's 'Pesni zapadnykh slavian' [Songs of the Western Slavs, I 836]). ${ }^{23}$ Sedakova has said that 'in song a person does not engage in self-expression (except unwittingly), rather he wills himself to unite with something essentially other. ${ }^{24}$ We might say that song, for Sedakova, enacts the engagement with an other that the mirror also performs: just as the person contemplating a reflected self-image looks at something insistently separate from the self, for all its likeness, so song insists on a kind of otherness when it plays a melody that the poet does not own. For Sedakova, that journey toward forms of otherness can become a kind of travel away from goodness, which may be one reason why her mirrors involve distortions and why they have the potential to do harm or show us evil. ${ }^{25}$

Here there is also a journey away from the mirror itself. Better not to look at it, says the poet, and tellingly she places the mirror alongside ('riadom') a viewer, rather than propped up directly across. We see the mirror as object, rather than what it reflects. The poet records a wish to see something at once impossible and simple: all of life, all its vastness, concentrated into a space so small that one could grasp it visually. This fantastic concentration creates a vivid contrast to the profound attraction to wide open spaces felt elsewhere in Sedakova's poetry, for example in the 'ogromnyi dom' ('enormous house') that ends 'Piatye stansy' ('Fifth Stanzas') or the 'broad paths' ('shirokie puti') of 'Vzgliad kota' ('The Cat's Gaze'). ${ }^{26}$ Open space is revealed even in 'Zerkalo', in the final image of the sea. But it is death's sea, a surrounding space which is both infinite spatially and the end of all temporal boundary.

These paradoxical contrasts are at the heart of nearly all of Sedakova's poems and, in the mirror poems, the fundamental contrast remains the presence or absence of light. Sedakova's mirrors show a darkness that daily light hides, but it is a darkness in which much can be known even if it cannot be seen. In another of the Starye pesni, 'Starushki' ('Old Women'), Sedakova recreates this contrast in terms familiar from the visual arts. She expresses love for the faces of old women, and imagines herself as a painter in that moment of expressing affection (the painter seems to me to be Rembrandt, whose contrasts of light and dark fascinate Sedakova).

\section{Старушки}

Как старый терпеливый художник, я люблю разглядывать лица набожных и злых старушек: смертные их губы и бессмертную силу, которая им губы сжала. 
пятаки и легкие копейки...

Кыш! - говорит он детям, птицам и попрошайкам, кыш, говорит, отойдите: не видите, что я занят?)

Гляжу — и в уме рисую: как себя перед зеркалом темным. ${ }^{27}$

Old Women

As patient as an old artist,

I love to look long and hard at the faces of devout and evil old women:

their mortal lips and the immortal strength that pressed their lips together.

(It's as if an angel sits there, stacking money into columns: five-kopeck pieces and lesser ones... Shoo! - he says to the children, birds, and beggars, shoo, he says, go away: can't you see that I'm busy?)

I look - and I draw a picture in my mind: myself before a dark mirror.

'Zerkalo' concentrated vision as if through a lens the size of a lentil, but 'Starushki' deflects attention, rather than tightening it. It wraps its middle stanza in a sweeping parenthesis that offers an alternative sight to the old master painter. The angel shooing away children as he sits before stacks of money seems a more vivid subject to be painted, but perhaps he is merely a metaphorical substitution for the old women, who are forbidding in their own way, the stern line of their closed mouths turning into his reclusive wish to count coins. The poem goes on to a further substitution in the third stanza: the poet draws a mental picture of herself before a darkened mirror. The darkness renders the mirrored image obscure and inaccessible, but no less so than the old women or the angel, who are closed off to poet and reader alike. The old women, with their tightly closed mouths, refuse to open out into speech, and the angel speaks only to shoo away intruders. The poem contemplates imagined paintings that allegorize enigma, and thus it is no surprise that the poet, who seeks meaning, would be thrown back upon herself. Those who seek meaning are beggars and children, but meaning is reduced to the endlessly convertible coins stacked up by the angel. The stacks look like the narrow columns of this poem, but they also connote a more forbidding presence, a strange intrusion of commerce and accumulation into a poetic world of angels and old artists. The poet may be asking, though, with her dark mirror, whether she risks becoming one of those 'evil old women' because she is 'devout'. Her poem rejects such an easy equivalence, leaving instead the suggestion of an aesthetic artifact, an image made by the poet as painter where we see old women and an angel and fleeing children.

\section{Zhdanov's Reflection on Time's Depths}

Ivan Zhdanov rarely uses such aesthetic artifacts (but Sedakova does: we might think of her Stely $i$ nadpisi [Steles and Inscriptions, I982] as the most powerful representation of artifacts in 
Sedakova's work). Instead, he creates an indirect ekphrasis, transforming a scene of nature or what we might call the romance of the family into a stilled image held up for inspection. Here, for example, is his 'Portret ottsa' ('A Portrait of My Father'), which shows his characteristic forms of indirection and deflection. ${ }^{28}$ I mention deflection because Zhdanov's mirrors rarely stand flat and perpendicular, across from a viewer. The gaze travels circuitously, partly because the mirror has depths that absorb, twist, or redirect any look that presents itself..$^{29}$ You'll notice that right away in this poem, particularly in its striking first metaphor of depth.

\section{Портрет отца}

И зеркало вспашут. И раннее детство вернется к отцу, не заметив его, по скошенным травам прямого наследства, по желтому полю пути своего.

И запах сгорающих крыльев. И слава над желтой равниной зажженных свечей. И будет даровано каждому право себя выбирать, и не будет ночей.

Но стоит ступить на пустую равнину, как рамкой резной обовьется она, и поле увидит отцовскую спину и небо с прямыми углами окна.

А там, за окном, комнатенка худая, и маковым громом на тронном полу играет младенец, и бездна седая сухими кустами томится в углу.

И мак погремушкой ударит по раме и камешком чиркнет, и вспыхнет она и гладь фотоснимка сырыми пластами, как желтое поле, развалит до дна.

Прояснится зеркало, зная, что где-то плывет глубина по осенней воде, и тяжесть течет, омывая предметы, и свет не куется на дальней звезде. ${ }^{30}$

Gerald S. Smith has translated the poem so as to preserve its calm tone and seemingly simple directness:

\section{Portrait of $M Y$ Father}

And the mirror will be ploughed up. And early childhood will return to my father without noticing him, over the scythed grasses of direct inheritance, over the yellow field of its path.

And the smell of wings burning up. And glory over the yellow plain of lit candles.

And there will be gifted to each man the right to choose himself, and there will be no nights.

But one only needs to set foot on the empty plain, and it will entwine like a carved window frame, and the field will see my father's back and the sky with the right angles of a window. 
And there through the window a mean little room, and on the throne floor with poppyseed thunder plays a baby, and a grizzled abyss pining for dry bushes in the corner.

And the poppy like a rattle will bang into the frame and strike like a pebble, and it will burst into fire, and the shiny expanse of a photograph in damp layers like a yellow field will collapse to the bottom.

The mirror will clear up, knowing that somewhere deepness is floating over the autumn water, and heaviness flows, lapping over the objects, and light is not being forged on a distant star. ${ }^{31}$

Zhdanov begins with the metaphor of a field about to be ploughed up, a field that is like a mirror. He likes the suggestion of a wave or ripple across the surface of a mirror and it appears in other poems - 'Tikho serdtse, kak osen', gorit' ('The heart burns quietly, like autumn') and 'Oda vetru' ('Ode to the Wind'), to name two. ${ }^{32}$ The mirror in 'Portret ottsa', as elsewhere, offers something other than a reflection of a self-regarding face. The face is not seen, in fact, instead the plough turns up the poem's visible signs, exposing images of early childhood. The mirror bustles with life as it accommodates grasses and yellowing fields, and an interior domestic space and a window frame. Inside and outside are not separate, as we sense in the fourth stanza. The 'little room' has a floor scattered with signs of thunder and 'dry bushes' in its corner. The window frame copies the boundary that might mark a mirror, and both mirror and window behave as if they were the 'shiny expanse of a photograph', as the next stanza will have it, another flat surface with surprising depths or 'damp layers'. Those metonymies of rectangular space recall the shape of this poem itself on the page, which is to say, the verbal field to be plooughed. ${ }^{33}$

Let us inspect, then, the poetic text. Metrically, it uses an uncommon but traditional form, amphibrachic tetrameter. ${ }^{34}$ The metre appears in several early poems by Boris Pasternak, including 'Marburg' (I9I5), and 'Sestra moia - zhizn'" ('My Sister — Life', I922). ${ }^{35}$ Pasternak's poem 'Zerkalo' ('The Mirror', I920) is relevant here, too, given its title and central metaphor, although it uses stanzas that alternate amphibrachic tetrameter with trimeter. ${ }^{36}$ But Zhdanov's great strength is not metrical experimentation and 'Portret ottsa', like Zhdanov's poem 'Portret' ('The Portrait') in amphibrachic trimeter, ${ }^{37}$ lacks the rhythmic dynamism and the brilliant rhyme pairs of Pasternak's early work. There is something astonishingly humble in his inviting comparison with such poetic performances, like holding your work up to a mirror that exposes its lesser shine. Yet the comparison does justice to Zhdanov's visual imagery. His poems often resemble the slightly surreal, densely imagistic poetry of Pasternak's early work. ${ }^{38}$ Zhdanov mixes interior space with larger public places, as Pasternak did in 'Marburg' and especially in 'Zerkalo', where the scene reflected by the mirror seems to bring the garden path and the swaying pines indoors. Zhdanov also animates the natural world in a way that recalls Pasternak. In 'Portret ottsa', the self-regarding father and the poet who sees him are not the only points of view: the one line in the poem in which the work of seeing is described has it that 'the field will see my father's back', which is to say that the natural world looks at a person rather than the other way around. ${ }^{39}$ That switch also reminds us of Pasternak's lyrics. ${ }^{40}$ So alive is the natural world, so much like a person, that it exists in an emotional as well as sensory register. Intense emotion is damped down in Zhdanov's poetry, by comparison, and rather than categories of passion, we encounter numbed objects. 
Zhdanov describes a quiet world, presenting yellowing fields and deep, autumn waters more often than thunderstorms or Pasternak's beloved wind. The greater stillness eases visual inspection of a reflected scene, which is one way to describe what happens in 'Portret ottsa'. The stillness also signals the ekphrastic project inherent in Zhdanov's mirror poems (Murray Krieger has influentially named the principle of ekphrasis as the 'still moment'), ${ }^{41}$ and it is an aspect of Zhdanov's work that makes it most like that of Sedakova. But he suggests forms of dynamism that gently shake up any possibility for true stillness: like the Romantic poets, he prefers transitional times of day (sunset) or seasonal change (especially autumn), and he often describes the inception of an action (the coming of rain, the onset of song), so that activity subtly makes its way into even his calmest poems.

The result is dynamic temporally as much as kinetically, seen in the father's vision of early childhood. The 'mean little room' ('komnatenka khudaia') suggests an absence of embellishment - which would be consonant with descriptions across Zhdanov's poetry. The natural sights and interior details have an elemental feel, and elsewhere we often find unnamed rivers or simply the mention of water, a path, rain, or snow. Such elements are bare, nearly all the adjectives that could describe them stripped away. The resulting narrative thus rises to the level of myth, so that the child who plays in straitened circumstances is nonetheless playing with a full sense of power - he is Zeus, lying about on a floor as if it were a throne, and hurling thunderbolts. The poppy seeds appear in other Zhdanov poems as a traditional poetic topos for death, for example, in the beautifully Orphic poem 'Voda v glazakh ne tonet priznak grusti' ('Water does not sink down in the eyes — a sign of sadness'). ${ }^{42}$ In 'Portret ottsa', the poppy seeds metonymically rattle around in the child's toy, but, again, when the noise of thunder is compared with the shaking sound of seeds, there is no drop in intensity. On the contrary, the rattle is incendiary, able to strike against the window frame and cause it to burst into flames. The window frame is a welcome image in the poem, I might add, not just for its association with rectangles, but also because it enables the nicest rhyme, 'po rame'/ 'plastami'.

The depths of those 'plasty' return us to a metaphor (ploughing) found in line I, but the effect of the closing stanzas is more one of variety, rather than repetition: a dazzling mix of mirror, swimming, seasons, weight and light. Zhdanov's metaphors, in fact, define his poetics. Why are there so many of them? One possibility is that they might be metaphors for one another - they might, in a sense, be equivalences. ${ }^{43}$ But such a reading mistakes the smooth intonational feel of the poetry (which, in turn, is amplified by epithets suggesting smoothness, quietness, calm) for an easy or unruffled surface of thought. Zhdanov's point is not to make the metaphors identical, but to recognize how, in their multiplicity, they represent poetic thinking as an endlessly deferred process of substitution. Zhdanov's mirrors often fail to reflect back what is before them, as if every metaphor were insufficient. Or the seen image might recede before the eyes - which is also what happens in this poem, when the mirror's clearing out is predicted. There is a restlessness in this mode of composition, an undercurrent of dissatisfaction that occasionally turns to palpable distress.

Zhdanov makes the mirrors themselves a metaphor in his poetry, in fact they constitute one of his most frequently used and most effective tropes. ${ }^{44}$ His mirrors are never merely reflective surfaces. If, in the visual arts, a represented mirror can seem to disappear, the better to render the reflection, the opposite happens here. ${ }^{45}$ The process of reflection matters more than the often unseen image, and, as in Sedakova's 'Zerkalo', the mirror's surface gets attention in its own right. ${ }^{46}$ Zhdanov breaks the natural tie, in other words, between the mirror and its 
principal attribute, a capacity to reflect light. Mikhail Epshtein has rightly observed that the 'properties of things are more primary than the things themselves. .' in Zhdanov's poetry. ${ }^{47}$ Zhdanov's metaphors work as metonymies, and his lyric hero has a relationship to the natural world best described as metonymic. ${ }^{48}$ Roman Jakobson first formulated this pattern with respect to Pasternak. Pasternak's example is again pertinent to Zhdanov, we note: Jakobson writes that 'in Pasternak's poetry, images of the surrounding world function as contiguous reflections, or metonymical expressions, of the poet's self. Jakobson also finds that 'Pasternak's poetry is a realm of metonymies awakened to independent life. The footsteps of the tired hero, themselves longing for sleep as he is, continue to live and move behind him. ${ }^{49}$ In 'Portret ottsa', the speaker emerges in a contiguous relationship to his father, which is to say, in a metonymic relationship, and it is the differences between them that give the poem its energy and also its mystery. ${ }^{50}$ The father's world is one in which there are no nights, but, for the son, there is deep heaviness and a lack of starry light in the poem's end..$^{51}$ The father sees reflections of freshly cut grasses and yellow fields, but for the son the yellow field collapses, there are only autumn waters to contemplate. To say that the son is relegated to a lesser world marked by loss and contemplation is only to say that he is a poet, one who seeks the radiance hidden in a dark world. ${ }^{52}$

\section{Sedakova Reflects on Darkness}

Such a phrase - the one who seeks the radiance hidden in a dark world — also well describes the poetry of Ol'ga Sedakova. In 'Legenda shestaia' ('The Sixth Legend') she shows mirrors to contain that world of darkness. With its title, 'Legenda shestaia' promises sequence and narrative as well as the explanatory force of legend; it appeared in her book Dikii shipovnik, with other such legends. All tell the life of a saint, or someone very like a saint. ${ }^{53}$ The feel, though, is more like that of a parable ('pritcha'), a term that appears in the final line of this poem, where details are sparse, and the identity of the monk unimportant. What matters is the encounter of self with soul, of darkness with light.

Легенда шестая

Когда гудит судьба большая, как ветер, путника смущая, одежду треплет - и своя душа завидней, чем чужая, монах старинный вопрошает: - Скажи, кому подобен я? -

и видит: зеркало живое, крылатое, сторожевое, журча, спускается к нему и отражает ту же тьму, какую он борол. Но в нем, в дыханье зрячем за стеклом, она - как облако цветное, окружена широким днем.

Так чья-нибудь душа живая не вытерпит прямого дня и, горе горем прикрывая и слово словом заслоня, 
тьму путевую соберет

вокруг себя — и в ней пройдет.

И в ней огонь его горит.

И свет, как притча, говорит. ${ }^{54}$

The Sixth Legend

When fate in its hugeness roars

like the wind, it confuses the wayfarer's path

and rumples his clothes - and one's own soul

is more enviable than someone else's -

the ancient monk comes to ask:

"Tell me, to whom do I bear resemblance?"

and he sees that a living mirror,

winged for flight, standing guard,

murmuring, is descending upon him -

and it reflects the same darkness

he had fought. But in it,

in the breathing that can see past the glass,

the soul - like a coloured cloud -

is surrounded by broad daylight.

Thus no one's living soul

can bear the light of day,

and. covering over grief with grief,

and shielding one word with another word,

it will gather the darkness of the path

all around itself — and it will cross over in darkness.

And in the darkness, his fire burns.

And light, like a parable, speaks.

The fire and the light in the final two lines of this poem diminish the absolute darkness with which it otherwise would end. Darkness makes possible a mind turned back on itself, as Susan Stewart writes in Poetry and the Fate of the Senses: 'Frozen, voiceless, a prisoner without sentence, the mind in the dark has no object to reflect on and no object to limit the endless racing of its reflections. ${ }^{55}$ Darkness would seem to stop thought, to create a prisoner of the mind, in Stewart's terms, but for Sedakova (who accepts the Christian framework on which Stewart bases her negative reading of darkness), darkness makes light possible. In this insistence on both light and dark, she resembles the Petersburg poet Elena Shvarts (who has commented that her very name, in its Greek and German origins, fates her to address both light and dark). ${ }^{56}$ Sedakova's monk has fought against darkness, yet he sees the dark looming up when he looks into the living mirror. The revelation of darkness is prompted by the monk's asking a question of resemblance: 'Skazhi, komu podoben ia?' The concept of likeness here invokes both the rhetorical and the theological realms, the latter in the very particular form of likeness we expect from icons ('prepodobnyi' being an epithet of reverence for a saint, for example). The living mirror that flies down to the wayfarer, in other words, shows him his soul in the same way that an icon shows the essence of a saint or prophet. The likeness is also, however, a question of language, where the capacity of words to render the seen world is put to the question. The monk is searching for the figurative powers of language, for a way to see the words shielded by one another.

When the monk asks the question of resemblance, he asks for a metaphor, we might say, but he gets the metareal. Mikhail Epshtein has defined metarealism in terms of the way it uses metaphor, and his emphasis on multiplicity remains useful: 
Metarealism, if one can use this word to name a poetic tendency, discovers a multiplicity of realities: the reality that is accessible to the vision of an ant, and the reality that is reduced to a mathematical formula, and the reality about which one says that 'the heavens shuddered'. The metareal image is not simply a reflection of one of these realities (that would be mirror realism), nor does it simply compare or imitate (that would be metaphorism), nor does it refer to one or the other by means of allusion or allegory (that would be symbolism). Rather, it opens out their originary complicity and mutual transformation, which is to say, the authenticity and inevitability of miracle. ${ }^{57}$

Getting to the metareal, Epshtein suggests, is like getting a miracle, and who better to seek that miracle than an ancient monk, whose reward is the miraculous flying mirror of revelation and enigma. The complicity here is one of the senses, which Susan Stewart told us to expect. The phrase 'seeing breath' ('dykhan'e zrachem') brings together the warmth of breath and the discernment of eyesight. The monk seems in the end to see the soul, which must protect itself against the glare of daylight first with a mantle of technicolor clouds, and then with gathering darkness. But in this miraculous mirror the monk is vouchsafed knowledge of the soul, guaranteed to him just as life itself would be proven, by the imprint of breath's moisture and warmth on the glass of revelation.

I began by speaking of mirrors as a metaphor for difficulty, but 'Legenda shestaia' might instead seem a model of simplicity. The limpid clarity of Sedakova's diction, her ease here with iambic lines and stanzas of varying length make 'Legenda shestaia' itself seem the accessible parable it mentions in its last line. We will be doing an injustice to this poem if we believe too readily in its ease, a tendency that this essay may paradoxically enable because Zhdanov can seem, by comparison, so complex. There are other poems by Sedakova, to be sure, that use complex chains of metaphors or apparently quick change of topic ('Gornaia oda' and the five long 'Stanza' poems come quickly to mind as examples), but the poems in which more is left out than is uttered may actually reveal Sedakova's range as a poet more vividly. ${ }^{58}$ Formal and lexical simplicity are both present in 'Legenda shestaia', where the rhymes draw so little attention to themselves by their astonishingly narrow phonetic range - these twentytwo lines rely on only seven phonetic combinations, themselves not especially disparate. Another formal sign of sameness occurs in the poem's syntax of repetition ('gore gorem prikryvaia/ i slovo slovom zaslonia'). The poem, as so often happens in Sedakova's work, performs an intensely disciplined act of limitation, within which we begin to hear the subtle repetition and variability that Epshtein told us to expect of the metarealist lyric.

\section{Zhdanov Reflects on Desire}

I conclude with a poem by Zhdanov that comes up against a different set of limits. I have mentioned it once already, "Voda v glazakh ne tonet - priznak grusti' ('Water does not sink down in the eyes - a sign of sadness'), and might have brought it up still earlier in discussing the friendship between the two poets. Zhdanov dedicated this poem to Sedakova, although he was required to remove the dedication when the poem was published (in Soviet times) and the dedication has never appeared in print. ${ }^{59} \mathrm{He}$ may have chosen this poem to address Sedakova for its watery images, so important in her work, and perhaps as well for the way in which he represents pain as an exquisite form of song (compare her two-part poem 'Bolezn'"/ 'The Malady'). ${ }^{60}$ In 'Voda v glazakh ne tonet', Zhdanov further abstracts many of his familiar images, anchoring them by references to ancient myth. In stark contrast, the poem also refers to the contemporary world of cinema (metonymically, a revision of the trope of the 
photograph seen already) and petroleum. One task of the poem is to establish the connections among these quite different temporal, experiential, and cognitive realms, to ask what a poet does with an experience of descent into something like hell when the blackness reminds him of the mundane, not the transcendent. But the most striking aspect of the poem is its opening, where Zhdanov proposes three apparent equivalences - their enormous imbalance well demonstrates his way with metaphor. He seems almost to suspect that readers might be reading his metaphors as equivalent terms, and he parses the distinctions very deliberately.

Вода в глазах не тонет - признак грусти.

Глаза в лице не тонут - признак страха.

Лицо в толпе не тонет - признак боли.

Боль, как пещера, вырыта в тумане -

в газообразном зеркале летейском, толпящемся в преддверии страданья.

О, если б кто-нибудь в пещеру эту своим лицом вошел, он бы услышал, что боль поет, как взгляд поет в ресницах.

Черна, как нефть, готовая взорваться, она плотней кассеты с кинопленкой, где в каждом кадре увяданье мака, где в каждом кадре мак меняет кожу, и против шерсти зеркало ласкает, оно в ответ чернеет и клубится.

Лицо в толпе не тонет и уходит.

Ему бы оглянуться, но в тумане лишь взмахи весел, плеск и скрип уключин. ${ }^{61}$

Water does not sink down in the eyes - a sign of sadness.

Eyes do not sink down in the face - a sign of fear.

A face does not sink down in the crowd - a sign of pain.

Pain like a cave dug out of the fog -

in Lethe's gas-shaped mirror, crowding into the threshold of suffering.

$\mathrm{O}$ if only someone entered this cave with his face, he would hear what pain was singing, he would hear the glance singing in the eyelashes.

Black as oil that is ready to burst out, the pain is more thickly solid than a box holding a film ${ }^{62}$ where in every frame the poppy fades,

where in every frame the poppy sheds its skin and rubs gently but the wrong way against the mirror's fur, the mirror answers by swirling up in blackness.

The face in the crowd does not sink down, it departs.

It should turn and look back, but in the fog there are only the flapping of oars, the splash and scrape of rowlocks.

The metaphors that open the poem are meant as enigmas, three enchained lines connected by a repetition of nouns, each pushed into the next line as if they were causally related. The lines' 
syntax is their real similarity, with the same verb negated in each line, the same dash breaking each line that seems like an equal sign. But the left side of the line is a syntactically complete unit that has its own mysteries (what does it mean to say that water, eyes, and faces float on surfaces to which they have no necessary relation — indeed, how can water float?). This kind of improbable image attracts Zhdanov, however, as in a line from 'Portret ottsa': 'deepness is floating over the autumn water'/ 'плывет глубина по осенней воде'. Не explores the heaviness of what seems air-filled or lofty, and in this stanza he finds a syntactic equivalent for that act of measuring weight. Here, syntax is a scale that estimates the weight of words: the left side of the lines weighs more, one iamb more, to be precise, than the right-hand side, where all is simpler - two nouns in genitive relation, and one of those nouns, 'priznak', is repeated in all three lines. The right-hand side of the lines makes things seem simple: something signifies pain or sadness, which is the expected stuff of lyric poems. ${ }^{63}$ And the signifiants, on closer inspection, lose some of their mystery: water that does not sink down in the eyes become tears running down the face, quite a normal sign for sadness, if expressed unconventionally; eyes that do not sink down into the face are popped out with fear; and the face that stands out, solitary, in a crowd, conveys the pain of isolation, an underlying tonality in Zhdanov's poems although a theme he addresses only indirectly. He keeps a distance from direct expression of emotion by striking the analytic posture of these lines. Negations begin and end this poem for a further reason, then - to make the poem a record of emotions it does not actually express.

By invoking the discourse of feelings, Zhdanov teaches readers to look for what is expected in a lyric - and rightly so, his form and lexicon are often traditional - but to expect to find it recast, particularly in terms of the imagery. ${ }^{64}$ Most fraught is the relation of part to whole, another confirmation that Zhdanov is a chiefly metonymic rather than metaphorical poet: eyes to face, faces to crowd. Parts don't disappear into the whole, they stand out. These failures to disappear signify pain, fear, and sadness, which in turn signify lyric poetry (could there be a more predictable list of themes for the lyric?). The face that ought to turn and look back in the last stanza is that of Orpheus, who for so many poets in and after modernism (Rilke and Tsvetaeva among them) is himself the sign of the poet. Susan Stewart only slightly overstates the case when she writes that 'the story of Orpheus underlies every poem. The poet risks the dangers of silence and darkness, bringing the message of human emotion to the gods and carrying back news of the gods to men'. ${ }^{65}$ But Zhdanov creates an Orpheus whose experiences have been modified, one who hears the stuff of poetry when he descends into the underworld. Zhdanov has effectively mapped Pushkin's 'Prophet' ('Prorok', I 826) onto the Orpheus myth: normally, Orpheus has long had his poetic gifts before using them to charm the denizens of the Underworld, but in this poem, he seems to learn how to be a poet while there, just as Pushkin's prophet learns to see and hear the world anew. What the poet in Zhdanov's poem sees is a world of pain, pain ready to burst out as oil might gush out of the earth.

What will he do with that pain? The poem's answer is ambivalent, transforming Orpheus's mistake (looking back at his Eurydice, thus losing her) into a failure to turn back. One hears that as a failure to imprint into memory the lessons of the Underworld, with the result that Orpheus (like the poet who writes this poem) hears only the splash of oars and rowlocks as the boat rows away. Orpheus hears, in other words, only the sound of his own departure, as visual mirroring becomes a form of auditory narcissism. He has failed to comprehend the truth of the Underworld, that it is a place of death. Thus, the poppy, traditionally associated with 
death especially in a context linked to antiquity, as here, fades from view or sheds its skin. It is not a flower (or seed) whose symbolism of death or sleep the poet can capture. Nor can the mirror capture it, but it can be affected by the poppy, which rubs blackness against it. That blackening stops the mirror from reflecting light, with two entirely contradictory, but fascinating, results: on the one hand, the mirror becomes doubly implicated in the poem's acknowledgment that it cannot do what it has set out to accomplish, for the mirror fails to act as a reflecting surface; on the other hand, it becomes absorptive when it blackens, as if it could take in (but perhaps not return) the effects of all it has encountered (death, loss). The next metaphor similarly opens out two very different possibilities. The mirror lacks the solidity that could let it be a reflective surface - in this poem, its substance is the wrong state of matter; it is gaseous rather than solid. But as an airy substance, it seems to turn from matter to spirit, which is to say that, having taken in the truth of death and loss, it becomes ghostlike. The mirror may not be able to reflect on what is seen, just as Orpheus, standing in for the poet, does not turn back to see what he is losing. But the poem, even without the agency of poet or mythic figure, records the loss with eerie stillness, a mere sound of oars splashing in water.

Perhaps it is inevitable, in a study of poetry and mirrors, that one would end with an image of loss: Lacanian psychoanalytic theory has taught us to notice the way mirrors cannot represent the image before them, and it has left us all too aware that the effect of the mirror stage in psychological and linguistic development is an awareness of the gap between reality and language. That aspect of the work of mirroring is especially well seen in a poem by Sedakova that shows a woman looking into a mirror — 'Zhenshchina u zerkala' ('Woman at the Mirror') ${ }^{66}$ Sedakova's poem emphasizes, perhaps more than any poem discussed here, with the exception of 'Voda $\mathrm{v}$ glazakh ne tonet', how much that glance at a mirror is an expression of desire. An American poet, Ann Lauterbach, has written revealingly of this linguistic glance in a poem entitled 'Tent'. She urges us:

\author{
not to look out or at, but into. \\ Come closer, so close \\ What you see can be seen as hindsight. \\ $[\ldots]$ \\ This is another way of speaking about intention, \\ about the theater of gathering. ${ }^{67}$
}

Lauterbach invokes two forms of thought that take the idea of vision in unexpected directions, although not unexpected for Sedakova and Zhdanov, as has been shown here: depth and temporality. When Lauterbach hopes to look 'into' an object, she is seeking to penetrate its depths; in Sedakova's and Zhdanov's poetry, this search also becomes a quest for transcendence. Another preposition, then, could be added into Lauterbach's sequence, giving us 'out', 'at', 'into', and 'beyond'. ${ }^{68}$ More important, the reward of Lauterbach's glance is 'hindsight', which means that the reflected sights promised in her poem constitute a glance into the past. Particularly in Zhdanov's 'Portret ottsa', that backward glance becomes a look to one's own history, and in 'Voda v glazakh ne tonet', the glance encompasses a mythological past and a dangerous backward glance at the beloved. There is a third form of thought here as well, one that inevitably inflects the other two, and that is desire, what Lauterbach calls 'speaking about intention'. This notion of 'intentionality' is challenged in poems that veil or obscure what might otherwise be rendered visible, with the result that desire remains in play throughout the poetry of Zhdanov and Sedakova. These three terms - depth, temporality, intentionality - imprint their work to envision the world, marking it with a distinctive signature. As 
comparisons with Lauterbach and others in this essay suggest, the work of vision and verbalization is not unique to Zhdanov and Sedakova, rather it marks their connection to a world of poetry, where seeing — in various directions and intensities - becomes the work of poetry. For Zhdanov and Sedakova, reflection is what makes valuable any of these acts of seeing: reflection as thought, and reflection as the mirror of poetry itself.

1 W. J. T. Mitchell, Picture Theory (Chicago: University of Chicago Press, I994). Mitchell both extends the 'linguistic turn' made famous by Saussure and resists the call of philosophers like Richard Rorty to rid philosophy of its visual metaphors. For Mitchell, the fascination with the visible can be historicized and theorized, and I am following his lead in suggesting here that reading the visual turn can re-align the hierarchies among poets and the place of poetry more generally in contemporary culture.

${ }^{2}$ Mikhail Epshtein called attention to Zhdanov and Sedakova and first placed them among contemporaries when his essay first appeared in Voprosy literatury in I986. The essay is now available in English: Mikhail N. Epshtein, 'New Currents in Russian Poetry: Conceptualism, Metarealism, and Presentism', After the Future: The Paradoxes of Postmodernism and Contemporary Russian Culture, tr. Anesa Miller-Pogacar (Amherst: University of Massachusetts Press, I995), pp. I9-50; for the original of Epshtein's essay, which has since appeared in several revisions, see 'Pokolenie, nashedshee sebia (o molodoi poezii 8o-kh godov)', Voprosy literatury, no. 5 (I986), pp. 40-72. See also O. I. Severskaia, 'Metarealism: Iazyk poeticheskoi shkoly: sotsiolekt — idiolekt/ idiostil', Ocherki istorii iazyka russkoi poezii XX veka: Opyty opisaniia idiostilei, ed. V. P. Grigor'ev (Moscow: Nasledie, I995), pp. 54I-557, which subtly takes issue with some of the premises behind Epshtein's work; her emphases pertain best to the poetry of Parshchikov, Dragomoshchenko, and Aristov.

${ }^{3}$ Konstantin Kedrov, 'My - metametaforisty', Metakod i metametafora (Moscow: DOOS, Izdanie Eleny Pakhomovoi, I999), pp. I7I-I96. Kedrov taught a seminar on 'metametaphor' which included Zhdanov among its participants. See Kedrov, Poeticheskii kosmos (Moscow: Sovetskii pisatel', I989) and Entsiklopediia metametafory (Moscow: DOOS, Izdanie Eleny Pakhomovoi, 2000) for the fullest explanation of his theory and practice.

${ }^{4}$ Jean Starobinski, Jean-Jacques Rousseau: la transparence et l'obstacle (Paris: Plon, I957).

5 A memorable contemporary American poem that takes on the challenge of self-reflection is C. K. Williams's 'Glass,' in Williams, Repair (New York: Farrar, Straus \& Giroux, I999), p. 32. I am grateful to Melissa Feuerstein for bringing this poem to my attention; she writes about it compellingly in her forthcoming dissertation, Object Poems, Department of Comparative Literature, Harvard University. It is also worth noting that poetry's self-regarding subject is often a woman, one whose gaze elicits the pleasures of narcissism or the rage of self-disgust, and women poets can rely on mythological parallels that add nuances of irony or richness to her self-presentation. Among Russian poets to use mirrors in this way is Inna Lisnianskaia. See especially Staroe zerkalo, a section of her book V prigorode Sodoma (Moscow: OGI, 2002), pp. 80-I06, for her most recent and extensive work with mirrors. But this is not a new topic for Lisnianskaia, who creates an irony in entitling the poems 'An Old Mirror': see also 'Ia v zerkalo vzglianu, byvalo' (I980) and 'Setchatka glaznaia' (I99I), in Lisnianskaia, Iz pervykh ust (Moscow: Izdatel'stvo 'Izograf', I996), pp. I4I and 27 I.

${ }^{6}$ Viktor Shklovskii, 'Iskusstvo kak priem' [I9I7], O teorii prozy (Moscow: Sovetskii pisatel', I983), pp. 925. An American poet whose poems on visual images are also often records of the creative process is Jorie Graham, too many, in fact, to cite. See, for example, 'My Face in the Mirror Tells a Story of Delicate Ambitions', in Graham, Hybrids of Plants and of Ghosts (Princeton: Princeton University Press, I980), p. 50; 'The Visible World', in Graham, Materialism (Hopewell, N.J.: Ecco Press, I993), pp. I39-I4I; 'Underneath (7)', in Graham, Swarm (New York: Harper Collins, 2000), pp. 53-54; and 'Philosopher's Stone', in Graham, Never (New York: Harper Collins, 2002), pp. 6-9.

${ }^{7}$ I use the signature rather than more conventional notions of subjectivity, as explored in Marjorie Perloff, 'Language Poetry and the Lyric Subject: Ron Silliman's Albany, Susan Howe's Buffalo', Critical Inquiry, 25 (Spring, I999), pp. 405-434.

8 I have not much attended here to the significance of Zhdanov's having come from the provinces. That origin, along with his idiosyncratic if not haphazard education, marks him as most unlike the erudite Sedakova (with her Moscow-Tartu education and rich knowledge of foreign languages and cultures). To see the bigger picture of how these two and other disparate poets were part of the modern poetry scene, see the excellent survey of later Soviet and early post-Soviet poetry in G. S. Smith, 'Russian Poetry Since I945', Routledge 
Companion to Russian Literature (New York: Routledge, 200 I), pp. I97-208. Smith rightly describes Zhdanov as an exception among the many other poets who survived by means of their connections to the official Soviet literary system (p. 205).

${ }^{9}$ Charles Lock, 'Debts and Displacements: On Metaphor and Metonymy', Acta Linguistica Hafniensia, Roman Jakobson Centennial Symposium, October IO-I2, I996, International Journal of Linguistics, 29 (I998), pp. $32 \mathrm{I}-337$, see p. 336. Lock is eager to extend Jakobson's argument about metonymy and metaphor as part of a general discussion of the inherently figurative nature of language (there is no such thing as the literal, as he says); my emphasis is less on placing this contrast into the philosophical tradition, as Lock does, and more on its actual working in the poetic tradition. I am more concerned with the shifting balance between the two tropes and I do not accept Lock's insistence that there is no metonymy in the unconscious ('the symbols of a dream cannot be in any significant respect contiguities: there is no contiguity in the unconscious'; p. 322).

${ }_{10}$ 'Vesna' is in the volume Vrata, okna, arki (Gates, Windows, Arches, I979-1983), published first in Sedakova, Vrata, okna, arki (Paris: IMKA, I986), pp. 84-85; and it can be found in Sedakova, Stikhi (Moscow: 'En Ef K'iu/ Tu Print', 200I), pp. 208-209. I use this most recent and fullest text of the poetry throughout.

${ }^{11}$ In 'Vesna', Khlebnikov is invoked as a spiritual guide and source for the poem's tropes of a landscape inscribed with the pleasure of writing. Sedakova has emphasized this invocation of the world inscribed with words as a fundamental theme of his work. See her essay 'Kontury Khlebnikova' (1985) in Sedakova, Proza (Moscow: 'En Ef K'iu/ Tu Print,' 200I), pp. 489-522, see pp. 500-50I; see also pp. 52I-522, where she contrasts Khlebnikov's handling of this trope (in his work, she says, not even a trope any longer) with Mande'shtam's. This aspect of Khlebnikov's work has also been thoroughly described in A. A. HansenLöve, 'Die Entfaltung des 'Welt-Text' — Paradigmas in der Poesie V. Chlebnikovs', Velimir Chlebnikov: A Stockholm Symposium, April 24, 1983, ed. Nils Ảke Nilsson (Stockholm: Almqvist and Wiksell International,I985), pp. 27-87. A significant poem illustrating this trope is 'Edinaia kniga', in Khlebnikov, Sobranie sochinenii, 6 vols. (Moscow: IMLI-RAN Nasledie, 2000-), vol. 2, pp. I I4-I I 5.

12 Jens Herlth, "Ol'ga Sedakova: Vesna,” Die russische Lyrik, ed. Bodo Zelinsky (Cologne: Böhlau Verlag, 2002), pp. 394-40I.

13 Compare Pasternak's elegy for the Biblical fig tree, "Chudo" ("The Miracle”), about which Sedakova would go on to write an illuminating essay. Sedakova, “'Chudo' Borisa Pasternaka v russkoi poeticheskoi traditsii," Pasternnakovskie chteniia. (Moscow: Nasledie, I998), pp. 204-2I4. The essay also appears in Sedakova, Proza, pp. 585-603, where the essay is dated I994.

14 'Elegiia smokovnitsy' was part of the book Sedakova called Elegii (Elegies, I987-I990). I cite from Sedakova, Stikhi, p. 294. Here and elsewhere, all translations from Russian are mine, unless otherwise noted.

15 Sedakova has noted that there is an 'unconscious repetition of the Easter readings' in this poem. See Sedakova, Valentina Polukhina, and Robert Reid. 'Collective Analysis of Olga Sedakova's “The Wild Rose",' Essays in Poetics, 22 (I997), pp. 237-257, see p. 249.

${ }^{16}$ In that habit of taking phenomena from the natural world as potential images for the poet's psyche, Sedakova most reminds me of the poetry of Jorie Graham, several of whose poems mentioned above (note 6) exemplify this approach to nature's shapes and sounds.

${ }^{17}$ A beautiful poem that works similarly is Sedakova's 'Portret khudozhnika na ego kartine' ('A Portrait of the Artist in his Picture'), Stikhi, pp. $83-85$, too long to treat here. The poem develops through a speaker, an addressee, a number of Biblical and mythological references, and the suggestion of a painting that compositionally resembles Sandro Botticelli's Mystical Nativity in many ways, but with some changed details, including the painter's self-portrait. See also 'Portret khudozhnika v srednem vozraste' ('A Portrait of the Artist at Middle Age'), published in Kontinent, no. I I6 (2003), magazine.russ.ru/continent/2003/i I6/sedak.html.

18 Sedakova, Stikhi, p. 243.

19 In the view of the late Manuk Zhazhoian, mirrors are a favorite image in her poetry, often twinned with that of a shade. Manuk Zhazhoian, 'Teni slov', in Zhazhoian, Sluchai Orfeia (St. Petersburg: AOZT 'Zhurnal "Zvezda", 2000), pp. 286-29I, see pp. 288 and 290.

${ }^{20}$ Sedakova, Stikhi, p. I49.

${ }^{21}$ In another poem in Starye pesni, 'Busy' ('The Beads') Sedakova more fully describes the world inside a small round object, including a garden, peacocks in the garden, a lake, fish in the lake. See Sedakova, Stikhi, p. I57.

${ }^{22}$ The link of hand to eye is best seen in one of Zhdanov's most mysterious mirror poems, 'Meleiut zerkala, i kukol'nye teni' ('Water does not sink down in the eyes'), in Mesto zemli, (Moscow: Molodaia gvardiia, I99I), p. 30. See especially the poem's conclusion, where the 'unseen hand' ('nezrimaia ruka') disappears behind the mirror. 
23 This form as well as the simple but very precise diction convey what Sedakova has called the cycle's 'folkchurch element' ('narodno-tserkovnaia stikhiia'): Sedakova, 'A Few Lines' ('Neskol'ko strok'), a bilingual afterword to Sedakova, The Wild Rose, tr. Richard McKane (London: Approach Publishing, I997), p. 228 (Russian), 232 (English).

${ }^{24}$ Ibid., p. 23 I.

25 Compare the observation by Sabine Melchior-Bonnet, tr. Katharine H. Jewett, The Mirror: A History (New York: Routledge, 200I), that modernist texts tend to use 'aggressive mirrors, blurred mirrors, empty mirrors' (p. 258).

${ }^{26}$ Sedakova, Stikhi, pp. 250 and 74, respectively. The latter 'Vzgliad kota', is especially pertinent to the mirror poems discussed here: it describes a mirror (in facets shaped to show anguish), and has a powerful contrast of open spaces with concentrations of emotion and action into the tiniest spot (in one case, a needle's tip).

27 Sedakova, Stikhi, p. I 56.

28 'Portret ottsa' was one of his earliest poems to reach print (in the almanac Poeziia in I979). It opens the section of his poems in the collective volume Poety-metarealisty, (Moscow: MK-Periodika, 2002), p. 7I, that gathered together the best work of Aleksandr Eremenko, Aleksei Parshchikov and Zhdanov and was selected by them. Its importance is also signalled by its placement as the first poem in Portret (Moscow: Sovremennik, I982), p. 5; and as the second poem in the succeeding two collections, Mesto zemli (I99I), p. 7, and Prisutstvie pogasshego ognia: Stikhi raznykh let (Barnaul: Izdatel'skii otdel mnogootraslevogo kooperativa 'Severnyi', I993), p. Iо.

An interesting feature of Zhdanov's volumes of poetry is that, with each new publication, he includes previously published poems as well as new ones, and he changes the order of the poems. One can conclude from this that the ordering is not chronological in any of the volumes, and that changing the sequence creates new contexts for reading the poems. Zhdanov consistently uses first and last poems to signal importance. (He also makes some small changes in a few of the poems, for example deleting the titles of the individual poems in 'Poezd' that appeared in Portret, pp. 57-62, in all later publications.)

29 The same is true of the most influential contemporary poem about mirrors in English, John Ashbery's "Self-Portrait in a Convex Mirror," in his volume of the same title (New York: Viking, I975), pp. I88-204. It seems unlikely to me that Zhdanov knew this poem - evidence that Russian avant-garde poets read Ashbery appears later and typically among those more oriented toward Western poetry. See, for example, the translations of Arkadii Dragomoshchenko: Dzhon Eshberi, "Zabytyi seks," Mitin zhurnal, no. 43 (I992), pp. I6-2I.

${ }^{30}$ Zhdanov, Mesto zemli, p. 7. I cite from this volume, somewhat easier to find than Portret, which is extremely rare.

31 Gerald S. Smith, ed. Contemporary Russian Poetry (Bloomington: Indiana University Press, I993), p. 259.

32 Zhdanov, Mesto zemli, p. 44 and Poety metarealisty, p. 90, respectively.

33 In that image of ploughing up a poetic text, and ploughing up time itself, Zhdanov echoes a metaphor found in the work of Osip Mandel'shtam. See, for example, the phrase 'Vremia vspakhano plugom'('Time is ploughed up') in the poem 'Sestry — tiazhest' i nezhnost', odinakovy vashi primety': Mandel'shtam, Polnoe sobranie stikhotvorenii (St. Petersburg: Akademicheskii proekt, I995), p. I49.

34 Amphibrachs and anapests gained more use in the beginning of the nineteenth century, although most poets chose a shorter line for these ternary metres. The longer line of amphibrachic tetrameter appeared in ballad or epic form, as in Pushkin's 'Song of Oleg the Wise' ('Pesn' o veshchem Olege', I 822), which alternates tetrameter and trimeter. M. L. Gasparov, Ocherk istorii russkogo stikha: metrika, ritmika, rifma, strofika (Moscow: Fortuna Limited, 2000), p. I 80. On ballads, see Michael Wachtel, The Development of Russian Verse: Meter and its Meanings (Cambridge: Cambridge University Press, I999), pp. 20-58.

The longer line puts Zhdanov into the company of many late Soviet poets, as we may infer from Mikhail Gasparov's statistical study of verse forms: M. L. Gasparov, 'Russkii stikh kak zerkalo postsovetskoi kul' tury', Novoe literaturnoe obozrenie, no. 32 (4/ I998), pp. 77-83, see p. 80. Gasparov also observes that, for some recent poets, like Timur Kibirov, the semantic aureole of specific metres has remained an important organizing force in their work, but in the post-Soviet period that has not been universally the case. Zhdanov, whose poetry is almost entirely written in traditional syllabo-tonic metres, often appears to have the semantic associations of specific metres in mind.

35 Boris Pasternak, Stikhotvoreniia i poemy, 2 vols. (Leningrad: Sovetskii pisatel', I990), vol. I, pp. I I4-I I7, I2O-I2 I. Compare also the amphibrachic tetrameter in such nineteenth-century poems as Pushkin's 'Tucha' 
('The Cloud', I835), which thematically resembles the natural imagery in 'Portret ottsa'. For 'Tucha', see Pushkin, Polnoe sobranie sochinenii, Io vols. (Leningrad: Nauka, I977-I979), vol. 3, p. 303.

${ }^{36}$ Beyond the more melodic feel of ternary metre, Zhdanov perhaps turned to it for the same reason as Pasternak, to avoid the familiar ring of iambic verse (Zhdanov's work is predominantly iambic). Gasparov has noted that Pasternak turned to ternary metres in I9I4-I9I6, especially to amphibrachs, as the least marked ('samyi bezlikii') rhythm, and as a way to avoid the problem of iambs inevitably sounding like Briusov's. He gradually returned to iambs, starting in Sestra moia — zhizn'. See M. L. Gasparov, 'Stikh B. Pasternaka', in Gasparov, Izbrannye trudy, 3 vols. (Moscow: Iazyki russkoi kul'tury, I997), vol. 3, pp. 502-5I7, see p. 5I2.

37 For 'Portret' see Zhdanov, Mesto zemli, p. 3 I.

38 The similarity to Pasternak's early work has also been noted briefly in Vladislav Kulakov, 'Po obrazu i podobiiu iazyka: Poeziia 80-kh godov', Novoe literaturnoe obrozenie, no.32 (I998), pp. 203-2 I4, see p. 204.

39 Sedakova can write similarly to displace subjectivity onto the described world. See, for example, 'Gornaia Oda' ('Mountain Ode') and 'Kitaiskoe puteshestvie' ('The Chinese Journey') in Sedakova, Stikhi, pp. I78I 82 and $269-287$.

40 This aspect of Pasternak's poetry is well described in Andrei Sinyavskii, 'Pasternak's Poetry', in Victor Erlich, ed. Pasternak: A Collection of Critical Essays (Engelwood Cliffs, N. J.: Prentice-Hall, I978), pp. 68-Io9. For examples of the intensely alive natural world, recall poems in which the sun can feel compassion for a train traveller, as in 'Sestra moia — zhizn', and a garden shake its fist at a mirror (in 'Zerkalo'). Or, as Pasternak wrote in 'Opredelenie tvorchestva' ('Definition of Creativity', I9I9), 'gardens, ponds, and enclosures' are nothing more than 'categories of passion' ('I sady, i prudy, i ogrady, / . . Mirozdan'e — lish' strasti razriady'). Boris Pasternak, Stikhotvoreniia i poemy, vol. I, p. I35. I take the English translation from Victor Erlich, 'Introduction: Categories of Passion', in Erlich, ed., Pasternak: A Collection of Critical Essays (Engelwood Cliffs, N. J.: Prentice-Hall, I978), pp. I-20, quotation from p. I3.

${ }_{41}$ Murray Krieger, Ekphrasis: The Illusion of the Natural Sign (Baltimore: John Hopkins University Press, I992), p. 3. Krieger also includes his I967 essay, 'Ekphrasis and the Still Movement of Poetry; or Laokoön Revisited' in this volume, pp. 263-288.

${ }^{42}$ Zhdanov, Mesto zemli, p. I 8. Compare Zhdanov's poem 'Prorok', for a poppy associated with injury but also fierce life: 'Mozhno vynut' zanozu iz maka zhivogo/ chtoby on perestal krovenit'sia v otvage' (Zhdanov, Mesto zemli, p. 86; 'Pluck the thorn out of the live poppy/ that it might cease its courageous flow of blood'). The poppy is Zhdanov's chief flower symbol, I believe, comparable to the rose in Sedakova's poetry. Her rose also bears a traditional symbolic association, that of the soul. See, for example, 'Dikii shipovnik', Stikhi, p. 20.

${ }^{43}$ At least one critic has read Zhdanov this way, discussing an early poem, 'Zapomnil ia tsvetnye sny shmelia' ('I have memorized the full-colour dreams of a bumble bee'). Nikolai Slavianskii, 'Vestnik bez vesti', Novyi mir, 6, I997, pp. 200-206. Slavianskii essentially puts equal signs between most of the poem's nouns and pronouns: bumble bee, dream, I, earth, notebook, face, and sky. Slavianskii's review begins as an engaged reading of Zhdanov's first collection of poetry, only to turn into a sarcastic denunciation of his second. Slavianskii also treated $\mathrm{Ol}^{\prime}$ ga Sedakova's poetry to a heavy dose of sarcasm: see his 'Iz polnogo do dna $\mathrm{v}$ glubokoe do kraev: O stikhakh Ol'gi Sedakovoi', Novyi mir, io (I995), pp. 224-23 I.

${ }^{44}$ Severskaia, 'Metarealizm', p. 55 I notes that the motif of a mirror's shiny surface appears frequently in the poetry of the materialists more generally, which she connects to the emptiness of subjectivity in their work. Zhdanov presents a less convincing example here than do Dragomoshchenko and Parshchikov. Mirrors are mentioned as a key motif in Zhdanov as well in V. Agenosov and K. Ankudinov, Sovremennye russkie poety: spravochnik (Moscow: Megatron, I997), p.42.

45 On mirrors in the visual arts, see Jonathan Miller, On Reflection (London: National Gallery Publications, I998), pp.II-I 5 .

${ }^{46}$ Zhdanov typically commands that attention by omitting any description of the reflected object, and by giving depth to the surface. Another good example is his poem 'Portret', which gave his first volume of poetry its title and which features a self-regarding person who falls into the mirror's depths.

47 Epshtein, After the Future, p. 42.

48 A particularly apt formulation of the differences between metaphor and metonymy appears in Barbara Johnson, 'Metaphor, Metonymy, and Voice in Their Eyes Were Watching God', A World of Difference (Baltimore, Md.: Johns Hopkins University Press, 1987), p. I55: 'they are classical tropes traditionally defined as the substitution of a figurative expression for a literal or proper one. In metaphor, the substitution is based on resemblance or analogy; in metonymy, it is based on a relation or association other than that of similarity (cause and effect, container and contained, proper name and qualities or works associated with it, place and event or institution, instrument and user, etc.)'. 
49 Roman Jakobson, 'Marginal Notes on the Prose of the Poet Pasternak', Language in Literature (Cambridge: Harvard University Press, I987), pp. 30I-3 I7, quoted from p. 307 and 308.

${ }^{50}$ The poem does not return the specificity of biography to the father (this poem never admits anything so intimate as the exploration of a father-son bond), but rather it makes the father the subject of myth or fairytale, an aim I find realized in the switch from a religious worldview in which the father's death means a transcendence of life - suggested in the poem's imagery of life's path and of the afterlife given to each of us - to a child's viewpoint, in which paths, mirrors, waterways and stars are the elements of an archetypal tale about pain and justice, isolation and reward.

51 Also missing in the poem are the signs of a father's love and devotion to his son. Zhdanov's other poem in memory of someone in his family shows deep feelings of love and loyalty ('Oblast' nerazmennogo vladen'ia', written in memory of his sister; see Mesto zemli, p. I04), but here the father's legacy is mediated through the land (the poet thus mentions the 'direct inheritance' of the fields). Zhdanov grew up in the Altai region in a family of nine children, the parents had been displaced as kulaks. Some sparse biographical details, barely more than these given here, appear in Agenosov and Ankudinov, p. 4I.

52 The search for light amid darkness brings Zhdanov on to divine terrain more familiar from Sedakova's work, particularly in his astral imagery. 'Kak eti zvezdy priruchit', izvestno tol'ko Bogu' ('Only God can know how to tame these stars'), writes Zhdanov in another poem (untitled, with the first line 'Kogda neiasen grekh, dorozhe net viny'['When sin is unclear, nothing is more precious than guilt'], a poem in which the stars look down on people and their fears, and sow their piercing light). See Zhdanov, Fotorobot zapretnogo mira (St. Petersburg: Pushkinskii fond, I997), p. I3.

53 Among the others, see especially 'Legenda deviataia: Otpevanie monakhini' ('The Ninth Legend: Funeral Service for a Nun') for its continuation of the motifs of night-time self-contemplation, and for its opening, a 'dark and golden frame/ surrounding an indescribable canvas' ('temnaia i zolotaia rama/ neopisuemogo polotna'). Sedakova, Stikhi, p. 40.

54 Sedakova, Stikhi, p. 22.

55 Susan Stewart, Poetry and the Fate of the Senses (Chicago: University of Chicago Press, 2002), p. I. Stewart goes on to emphasize how, in the Christian tradition, 'darkness remains . . . the place of error and shattered being where humans are halted form movement and knowledge' (p. I I). Sedakova will challenge an absolute association of darkness with evil.

Susan Stewart has also written about praise in poetry in terms that resonate with Sedakova's 'Legenda shestaia' and many other poems. In asking about the nature of knowledge uncovered in the praise poem, Stewart says that it is like asking 'why the gods must be told what they already know'. See Stewart, 'What Praise Poems Are For', PMLA, I20, I (January, 2005), 235-245, quotation on p. 236.

56 When asked how far she would allow herself to go into the darkness, Shvarts answered 'As far as it's possible to go.' She added that 'the realm of darkness is, in all probability, merely a shadow cast by the light; is the same light in a certain sense.' See Valentina Polukhina,' Coldness and Rationality', Brodsky Through the Eyes of His Contemporaries (New York: Macmillan, I992), p. 220.

${ }_{57}$ Mikhail Epshtein, cited in an addendum to Poety-metarealisty, p. 2I8. Similar ideas, although phrased differently and emphasizing the contrasts between metarealism and surrealism, appear in Epshtein, Paradoksy novizny: o literaturnom razvitii XIX - XX vekov (Moscow: Sovetskii pisatel', I988), pp. I60-I6I.

${ }^{58}$ I was led to wonder, in writing that sentence, whether there was any other contemporary poet who had explored so deeply the extremes of minimalism and maximalism. I wrote about some of the more maximalist poems in 'Thinking Self in the Poetry of Ol'ga Sedakova', Gender and Russian Literature: New Perspectives, ed. Rosalind Marsh (Cambridge: Cambridge University Press, I996), pp. 302-325.

${ }_{59}$ As noted to me in conversation with Ol'ga Sedakova several years ago and confirmed in an e-mail note, April 5, 2005 .

${ }^{60}$ Sedakova, Stikhi, pp. 66-67, and see her 'Predpesnia' (p. 35), which surely inspired him more precisely in "Voda v glazakh ne tone', starting with its epigraph: 'I pered nim vodoi smushchennoi tolpiatsia temnye slova...' ('And before him the dark words crowd together in turbid waters').

${ }_{61}$ Zhdanov, Mesto zemli, p. I8. The poem appeared first in Portret (I982).

62 I have translated 'kasseta s kinoplenkoi' rather literally as 'a box holding a film', to preserve the similarity to other tropes of holding or containment in the poem, although the phrase also simply means a videocassette.

${ }^{63}$ I am translating 'priznak' as 'sign' to emphasize its connection to acts of signification, but 'priznak' is more a symptom or an indication, thus a particular kind of sign, one which alerts us to expect the thing of which it is a symptom. Zhdanov also stays with signifiants that are appropriate to the semantic field of illness and pain. 
${ }^{64}$ The poem's use of blank verse fits the pattern, too. Its iambic pentameter is used in an unusual way: unrhymed lines in this metre usually alternate masculine with feminine endings as noted in Gasparov, Russkie stikhi 189o-kh - 1925-kh godov v kommentariiakh, p. 34. But Zhdanov ends all lines in feminine closure. And he uses these lines in three-lines stanzas, inviting us to look for terza rima rhyme. Instead, the absence of rhyme draws attention all the more intensely to the final words, where similarities in sounds start to seem like nearrhymes, and these connections in turn draw in other words from the lines, making the sound orchestration more palpable than it would be otherwise.

${ }_{65}$ Susan Stewart, Poetry and the Fate of the Senses, p. 256.

${ }^{66}$ In Object Poems, Melissa Feuerstein offers a splendid reading of this poem, particularly its representations of the gaps among language, object, image, and cognitive experience.

${ }^{67}$ Ann Lauterbach, Hum (New York: Penguin Books, 2005), p. 3.

68 The longing within language to become visual material is also very well expressed by another contemporary American poet, Barbara Guest, once a participant in the New York school and still an active presence on the poetry scene. In 'Poetry the True Fiction', Guest writes: 'Words without vision are deprived of stability. They cling desperately to a mirrored surface in an effort to attach themselves to a surface, because they have no direction and no stabilized vocation. They become furtive, these words, thirsty for a version of themselves that contains no failure of vision. Words contain their own beauty of face, but they desire an occupation. They cannot exist on beauty or necessity alone.' Like Zhdanov and Sedakova, Guest senses in language the wish to attach itself to a surface; like her, they will reject any satisfaction or comfort one might feel in that attachment. The word also always seeks to transcend the visible, or to plunge into the surface's depths. See Guest, Forces of Imagination: Writing on Writing (Berkeley: Kelsey St. Press, 2003), p. 29. 
Copyright of Slavonica is the property of Maney Publishing and its content may not be copied or emailed to multiple sites or posted to a listserv without the copyright holder's express written permission. However, users may print, download, or email articles for individual use. 